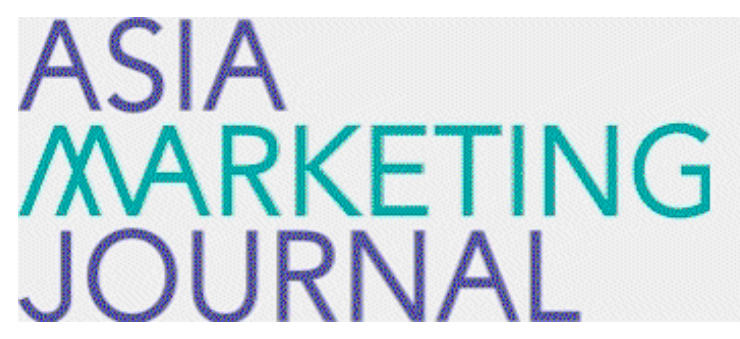

ASIA MARKETING JOURNAL

Volume 3 | Issue 3

Article 1

9-1-2001

\title{
관계지향성의 구성요인 및 원인과 성과에 관한 연구
}

Nak Hwan Choi

Young Ah Kim

Ho Jung Lee

Follow this and additional works at: https://amj.kma.re.kr/journal

Part of the Marketing Commons

\section{Recommended Citation}

Choi, Nak Hwan; Kim, Young Ah; and Lee, Ho Jung (2001) "관계지향성의 구성요인 및 뭔인 과 성과에 관한 연 구," Asia Marketing Journal: Vol. 3 : Iss. 3 , Article 1.

Available at: https://doi.org/10.53728/2765-6500.1067

This Article is brought to you for free and open access by Asia Marketing Journal. It has been accepted for inclusion in Asia Marketing Journal by an authorized editor of Asia Marketing Journal. 


\title{
관계지향성의 구성요인 및 원인과 성과에 관한 연구*
}

\author{
A Study on The Causes and Outcomes of \\ Relationship-Orientedness between Businesses
}

\author{
최낙환(전북대학교 경영학부 교수) \\ cnhemoak. chonbuk. ac. kr \\ 김영아(전북대학교 경영학부 강사) \\ nagasena@hanmai l.net \\ 이호정(전북대학교 대학원 박사과정) \\ Ihj-8301@hanmail.net
}

\begin{abstract}
본 연구는 자원의존이론, 거래비용이론, 관계계약이론 둥의 선행연구를 겁토하여 관계 지향성의 원인과 성과를 밝히고자 하였다.

먼저 구매기업과 공급기업간의 행동적 관계지향요인과 관계지향성 분석을 실시하였다. 행동적 관계지향요인으로는 정보교환, 조화노력, 행동적 규범, 업무결속을 들고, 관계지향성 분석을 위해 군집분석을 실시하였다. 연구표본에는 $\mathrm{C}$ 지역의 전문건설업체를 대상으로 500 부 의 설문지를 배포, 그 중 185 부를 회수하여, 적합한 설문 140 부가 사용되었다. 군집분석 결과 관계지향성 집단은 정보교환, 조화 노력, 협동규범 수용, 업무결속이 모두 높게 나타 났고, 비관계지향성 집단은 정보교환, 조화노력, 협동규범 수용, 업무결속이 모두 낮게 나타나 기업간의 관계지향성을 의미있는 2 개의 집단으로 나눌 수 있었다. 둘째, 기업간 관계 지향성의 영향요인으로 환경의 역동성, 대안의 이용가능성, 공급의 중요성, 상호호혜전략, 신뢰성을 검토하였다. 본 연구에서 선정한 관계지향성에 대한 영향요인들이 관계지향집단과 비관계지향집단으로 분류하는데 얼마나 유용하게 이용둴 수 있는가를 알아보기 위해 판별분석을 실시하였다. 관계지향집단과 비관계지향집단의 분류에 환경의 역동성, 대안의 이용가능성, 공급의 중요성은 영향이 없는 것으로 나타났으며, 호혜전략, 신뢰성은 의미가 있는 것으로 나타넚다. 셋쩨, 기업간 관계지향성의 성과로서 실현경쟁우위와 관계유지의도를 검토하였다. 관계지향성이 성과에 어떠한 영향을 미치는가를 검중하기 위해 MANOVA (multivariatee analysis of variance)분석을 실시하였다. 실중 결과, 관계 정도가 높은 집단이 관계 정도가 낮은 집단보다 실현 경쟁우위수준을 높게 지각하고 관계률 유지하려는 의도가 높은 것으로 나타났다.
\end{abstract}

* 논문접수: 01.08 게재 왁정: 01. 10

본 연구는 전북대학교의 연구비지원을 받아 수행되었습니다. 


\section{1. 서 언}

기업간 관계의 질이 마케팅 프로그램의 실행에 중요한 영향올 미치고(Ruekert, Walker and Roering 1985), 제품차별화에 기여하고(Porter 1985) 시장에 대한 진입장벽으로 작용한다(Reve 1986)는 주장과 함께 기업간 관계의 설계는 중요한 전락적 변수가 되었다.

기업간의 지배는 당사자들간의 상호인지, 계속적 관계유지, 관계종료 등을 포합하는 다차원적 현상이다. 이러한 현상은 자원의존이론, 거래비용이론, 관계계약이론 등의 다양한 이론들로 설명되고 있으며, 비소비시장의 지배나 기업간 관계에 관한 연구는 최종 시장지배에 관한 연구와는 다른 내용을 포함하고 있다.

거래비용이론(transaction cost theory)은 최종소비시장에서의 교환이론에서 이탈하여 체계 적인 지배(hierarchical governance) 현상올 설명하고(Williamson 1985), 기업이 교환 파트너의 기회주의적 행동가능성으로부터 거래를 보호하는데 가장 효율적인 지배구조를 선택한다고 제안한다. 유통기능을 내부화하는 것은 유통의 통제성을 높이지만 외부화하는 것과는 상충관계가 되어 비용효율성을 검토할 필요가 있게 한다. 그러나 비용과 통제의 관점에서 유통올 분석하는 것은 한계가 있다. 규모의 경제는 유통분석에서 고려되는 하나의 관련요소이지만, 통합시스템의 본질적 특성을 설명하는 것은 아니다 (Heide 1994). 특정 유통기능이 내부기능으로 된다고 해도 이에 대한 통제 메카니즘이 필요하며, 또 어떤 통제메카니즘을 사용할 것인가는 선택문제이다. 따라서 중요한 문제는 소유냐 또는 퉁합이나에 있는 것이 아니라 특정관계가 형성되는 방법이다.

자원의존이론(resource dependence theory)은 기업간 지배률 불확실성(uncertainty)과 의존성 (dependence)의 조건에 대한 전략적 반응으로 보고 있다(Pfeffer and Salancik 1978).

자원의존이론은 기업이 중요한 자원을 충분히 보유하지 않고 있다는 전제하에서 기업간 의존성을 다루고, 또 기업이 자원의 흐름을 퉁제할 수 없고 정확하게 예측할 수 없는 정도 가 클수록 불확실성이 크다는 관점에서 타기업과 공식적 또는 준공식적 연결관계를 구축 하고 교환관계를 구조화하여 불확실성올 극복하고 의존성을 관리하려 한다고 본다.

거래비용이론과 자원의존이론은 비최종시장 지배률 불확실성과 의존성에 대한 반웅으로 본다는 점에서는 맥락을 같이 한다. 그런데 거래비용은 관계구축의 효율성을 계산하지만 자원의존이론은 교환파트너의 수요충족 능력에 국한하여 성과를 다루기 때문에, 두 이론은 차이가 있다.

계약이론(contracting theory)은 관계적 지배(relational governance)의 확립을 다루고 있다 (Macneil 1980). 관계적 거래 즉 쌍방적 지배이론은 거래비용이론이나 자원의존이론과는 다른 관점에서 지배의 형태롤 다루기 때문에 차이가 있다. 즉 관계적 거래는 쌍방적 파워 시스템을 수용하여 개별기업의 목표들이 기회주의적인 자기의 이익을 억제하고 양자의 장기적 이익의 관점에서 달성된다는 점에서 차이가 있다. 그리고 신뢰(trust)와 몰입 (commitment)의 관계적 행동에 대한 효과(Doney and Cannon 1997; Morgan and Hunt 1994), 성과에 대한 관계특성의 효과(Mohr, Fisher and Nevin 1996)에 관한 연구들이 있다.

이러한 연구들은 관계와 관련된 구성개념들간의 관계를 검중하여 이론을 발전시켰다. 이들 이론과 프레임웍 각각은 서로 다르지만 중요한 상업거래의 일면들을 강조하고 있으며, 다양한 개념들이 관계의 이해와 관련되어 있기 때문에 다양한 개념들을 종합적으로 검토할 필요가 있다. 즉, 기업(구매자-빤매자)간의 관계성에 대한 포갈적인 검토가 팔요하다. 
Macneil(1980)은 Macaulay(1963)의 비계약적 기업관계에서 부분적으로 아이디어률 얼어 교환을 단속적(discrete) 거래와 관계적(relational) 거래로 구분하였는데, 단속적 거래는 개뼐 거래가 계약당사자들간의 과거 및 미래의 관계와는 독립적으로 이루어지며, 관계적 거래는 역사적이고 사회적인 맥락을 설명할 수 있으며 거래당사자들간의 상호이익을 중요시하는 의무감을 포함하고 있다(Kaufman and Stern 1988). 거래적 교환은 최소한의 개인적 관계에 의해서 또는 차후의 교환에 대한 예측이나 의무감이 없이 상품이나 성과률 대가로 받고 구매자와 판매자가 불연속적으로 교환하는 것이다. 관계적 교환은 협동적 행동, 당사자간의 상호 조정, 교환의 이익이나 공유, 그리고 미래의 교환에 대한 계혁 둥으로 설명된다. 그런데, Macneil(1980)은 순수한 거래적 교환은 찾아보기 어렵고 어떤 측면에서든지 관계 개념이 구매자와 판매자간의 대부분 거래에 작용하고 있다고 하였다. 즉, 거래적 교환개념과 관계적 교환개넘이 복합적으로 작용한다는 것이다.

그런데 거래비용이론, 관계계약이론, 자원의존이론 등의 공통점은 관계의 구축에 있지만, 관계의 구축을 서로 다른 관점에서 접근하고 있다고 볼 수 있다. 그러나, 서로 다른 이론의 관점을 모두 이용하여 관계지향성정도를 단일차원상의 연속선으로 설명할 수도 있다.

관계 마케텅(relationship marketing)에 대한 기존 연구의 입장은 교환관계에서부터 관계 지향적 관계까지의 연속적 고객관계를 가정하고 있다(Dwyer, Schurr, and Oh 1987; Jackson 1985). Anderson과 Narus(1991)는 거래적 교환에서 협동적 교환에 이르는 연속선상의 관점에서 고객을 분류해야 함을 주장하였다. 즉 기업은 모든 고객이 똑같은 관계를 원하는 것이 아니기 때문에 거래 마케팅과 관계 마케팅을 동시에 추구할 필요성을 역설하고 있다. Kumar, Scheer와 Steenkamp(1995)는 구성개념들을 종합적으로 검토하여 관계의 질(relationship quality)을 탐색하였는데, 관계를 설명하는 요인들은 상호간에 높은 상관관계가 있으며, 또 결합되어 관계정도를 단일차원상의 연속선으로 설명할 수 있음을 확인하였다.

한편, 구매자와 공급자가 상호간에 이익이 되는 전략적 결과를 얻으려고 노력할 때, 그들은 어떻게 독특한 환경, 각각의 능력, 인적자원들을 그들에게 유용하게 만들 수 있을 것인가를 반드시 고려해야 한다. 희사의 성공은 부분적으로 다른 회사에게 의존한다는 것울 깨달고 이해해야 한다. 시스템 자원처럼, 상호 관계지향성정도에는 영향을 미치는 요소가 있다. 영향요소에는 양자를 둘러싸고 있는 외부 환경의 거시적 요소, 그 안에서 양자가 작용하는 조직 구조, 그리고 양자의 조직적 영역을 연결하는 상호 인간적인 관계의 미시적 요소가 포함된다. 이러한 요소들은 그 특징이 다양하지만, 그들의 일반적인 효과는 회사들로 하여금 노력을 늘리고 전략적 결과물의 성취를 지원하는 투자를 하도록 동기률 유발하고 촉진시킬 것임에 틀림없다.

따라서 본 연구는 첫쩨, 관계에 관련된 이론들을 검토하여 관계지향성의 행동적 구성 요소들을 식별하고, 둘째, 식별된 구성요소들에 의하여 관계의 지향성정도를 탐색하여 관계지향집단과 비관계지향집단을 구분한다.

셋째, 관계의 지향성정도(관계 지향집단과 비관계 지향집단의 구분)에 영향을 미치는 변수들을 식별하고, 관계지향성정도(관계 지향집단과 비관계 지향집단)에 따른 성과들을 탐색한다. 


\section{2. 구매자와 판매자간의 관계지향성의 구성요인과 관계지향성 분석}

\section{1. 관계지향성의 구성요인}

자원의존이론은 거래 당사자들이 만족에 이르는 과정을 강조하며, 의존성과 불확실성을 관리하는 테크닉을 강조한다(Anderson and Narus 1990). 거래비용분석은 거래를 지배하는 효율적인 구조를 확인하는 것에 초점을 둔다. 관계적 계약(relational contracting)이론은 거래비용이론이나 자원의존이론과는 다른 관점에서 쌍방적 파워시스템을 수용하여 지배의 형태를 다루기 때문에, 관계적 거래에서는 개별기업의 목표들이 기회주의적인 자기의 단기적 이익올 억제하고 양자의 장기적 이익의 관점에서 달성된다는 점을 다루고 있다 (Heide and John 1992).

거래비용이론과 자원의존이론은 비최종시장 지배블 불확실성과 의존성에 대한 반웅으로 본다는 점에서는 맥락을 같이 한다. 따라서 당사자간의 정보교환은 지배결속의 매개체가 된다.또한 거래특유자산(transaction-specific assets)은 교환파트너가 이탈할 수 없게 하고 또 이탈하려면 비용을 지불해야 하기 때문에 당사자간의 거래를 유도하는 매개체가 된다.

한편 자원의존이론의 관점에서 자기자원의 부족은 상대방 기업에게 의존하게 하며, 부족한 자원의 흐름이 자기의 통제하에 있지 않는 한 의사결정의 불확실성을 초래하게 된다. 따라서 교환 당사자 기업들은 상호 호혜적인 적응을 할 필요가 있게 된다. 즉, 상호간에 조화노력이 필요하게 되고 또 원활한 거래를 위하여 업무적인 결속이 요구된다.

관계적 계약이론은 기희주의적이고 단기적인 이익의 회생과 장기적 이익과 만족의 추구 관점에서 당사자들이 좀 더 큰 차원의 규범을 수용하여 교환이 배태되는 사회적 구조를 설명한다. 따라서 교환이 성숙되는 혀옹적 규범을 요구한다.

본 연구에서는 정보교환, 조화노력, 업무적 결속, 협동적 규범을 관계지향성의 구성요인으로 보고 설명한다.

\subsection{1. 정보교환}

정보교환(information exchange)을 양 당사자들에게 유용한 정보의 공개적 공유로 정의한다. 좀 더 공개된 정보 공유는 양 당사자에게 중요하고 좀 더 깊은 정보교환은 재산정보를 공유하려는 의지로도 나타난다. 실제로, 이것은 제품 설계의 초기단계에서 상대방을 관여시키는 것, 장부를 공개하고 비용정보를 공유하는 것, 미래의 제뚬 개발계힉을 논의하는 것 또는 공동으로 공급과 수요 예측을 수행하는 것을 포함한다.

최근의 정보기술의 발전과 제조업자의 품질강조는 많은 희사들로 하여금 보다 광범위한 정보 공유의 위헙과 보상의 상쇄(trade-off)문제를 검토하게 해왔다. 정보를 더 많이 공유하는 것은 제품의 품질올 향상시킬 수 있고(Emshwiller 1991), 신제품 개발올 용이하게 할 수 있다(Magnet 1994). 그러나, 정보의 공유는 한 당사자가 다른 당사자에게 기회주의적 행동을 야기할 수 있다(John 1984), 예를 들어, 어떤 공급자들은 거래기업의 이전 구매팀장이 자신의 가장 최신기술 청사진을 경쟁업자들에게 제공하였다고 주장할 수 있다.

Kelly와 Thibaut(1978)는 정보교환을 통하여 교환 당사자들은 그들의 상호적 행동들의 결과를 더 잘 이해하게 된다고 하였으며, Clopton(1984)은 좀 더 공개된 정보교환은 공동으로 
최적의 결과를 가져은다는 것을 발견하고 있다. 유사하게, Williamson(1985)는 정보가 충둘될 때 그리고 양 당사자사이에 공유되지 않을 때 시장실패가 더 일어날 것이라는 것을 제안하며, Macneil(1980)은 비밀스런 정보의 자유로운 교환온 보다 관계적인 교환의 한 특성이라고 주장한다. 정보교환의 기저에 있는 아이디어는 Mohr \& Nevin(1990)의 연구에서 경로 성과에 중심적인 의사소통 개념과 밀접하게 연관된다고 하였다. 따라서 이러한 문헌 속에서 정보교환은 관계지향성의 행동적 구성요인임을 파악할 수 있다.

\subsection{2. 조화노력}

Porter(1980, 1985)는 진출/진입 장벽에 기초해 산업의 임대-수익(rent-earning) 가능성을 측정하기 위해 산업구조의 분석올 강조하였다. 전략수행에서 조직의 역할을 강조하며, 조직의 자원, 능력, 핵심 능력 둥을 강조하였다. 이러한 자원들이란 “주어진 회사의 강점 또는 약점으로 생각되어지는 것"들이며, 이러한 것들은 유형 그리고 무형의 자산들을 포함한다. 이러한 영역에 대한 연구들은 회사를 분석의 기본적 단위로 보며, 경쟁적 이익은 단일회사에 의해 소유되고 퉁제되는 자원과 눙력으로부터 생겨난다고 본다. 이러한 중요한 자원들이 회사의 영역을 확장할 수도 있고 상호 조직적인 과정과 행위사이에 내포될 수 있다는 것을 인식하였다. Dyer와 Singh (1998)는 생산성 흭득은 조직이 기꺼이 특유의 투자를 하고 나름의 방법으로 자원들을 조합할 용의가 있을 때 가능하다고 주장하였다. 따라서, 조직사이의 관계는 경쟁적 이익의 원천이며, 양자는 분석의 적절한 단위가 되는 것이다.

기업간의 협력 과정온 공동작업에서의 학습곡선, 다양한 기술, 그리고 시간과 노력에 대한 상당한 투자를 포함한 회사의 시스템자원(미리 쉽게 세분화 될 수 없는 조직의 능력, 투자, 자원 사이의 직 간접적인 연결로 이루어진 복잡한 망을 포함하는 사희적으로 생성된 복잡한 현상)이다(Barney 1992; Fiol 1991). 이러한 협력과정의 가치는 독특한 특성으로부터 나오며, 회사간 관계의 특별한 톡이성과 협력적 과정이 경쟁자들에 의해 관찰되고 복제되기 어려울 때 의미가 있다(Dierickx and Cool 1989).

Dyer와 Singh(1998)은 비특이적 투자, 최소한의 정보, 조화 장치, 낮온 상호의존도 둥의 특징이 있는 전형적이며 적당한 거리를 유지하는 교환은 모방할 수 없는 톡이함이 결여되어 있으므로 다른 구매자-판매자 조합이 만들어 낼 수 있는 정도를 넘어서는 이익을 만들어 낼 수 없다고 주장하였다. 경쟁적 이익을 만들어 내기 위해서 회사는 그들의 자원을 전문화 시켜야 하며, 그들 스스로률 차별화 시켜야 한다(Amit and Schoemaker 1993). Dyer와Singh은, 회사는 적당한 거리두기 교환에서 벗어나서 특유의 투자, 지식 교환, 보완적 눙력, 그리고 보다 효과적인 관리 메커니즘올 통해 그들의 관계를 전문화시킴으로써 경쟁적 이익을 얻을 수 있는 기희를 만들어 낼 수 있다고 주장하였다. 따라서, 조직적 경계를 가로지르는 상호작용 양상과 조화노력(coordination effort)은 헌신적인 투자와 더불어 희사가 얻으려고 애쓰는 차별적인 이익을 생성하게 된다. 자본 연결에 대한 Harrigan(1986)의 연구는 경쟁적 혹은 전략적 목적에 대한 상호 조직적 전략은 분명히 실질적인 자원과 조화 노력올 필요로 한다는 것을 발견하였다. 전략적 결과물의 원천으로서 경쟁자가 모방할 수 없는 헙력 과정은 바로 두 가지-노력과 자원-의 조합으로 만들어진다.

관계적 적웅은 거래파트너의 필요 또는 눙력에 대한 과정, 제품 또는 절차적 적웅 투자이다. 이익을 만들어 내거나 손실을 막는 자원의 눙력은 외부 환경에 전략을 잘 맞추는 것과(Amit and Schoemaker 1993; Burns and stalker 1961; Porter 1991; Thompson 1967; Wernerfelt and Aneel 1987), 회사에게 유용한 조직과 인적 자원들의 조화에 달려 있다. 
관계특정적 적웅들은 가치를 창조하는 만큼 전환비용(switching costs)을 형성하는 데 기여 한다(Jackson 1985).

사희교환이론은 적웅을 투자로 언급하면서 상호적인 관계에서 적웅의 역할을 분명히 고려 한다(Rusbult 1983). 특정 기업의 자산상의 결핍은 관계톡정적 적웅의 아이디어와 밀접하게 관련되어 있지만, 거래비용분석은 분석의 단위로써 거래에 초점을 두기 때문에 적웅을 전형적으로 특정자산의 지배에 대해 외생적인 것으로 모형화 한다. 따라서 조화노력은 거래관계를 형성하는 행동변수이다. 본 연구는 관계를 분석의 단위로 처리하기 때문에 적웅 즉 조화노력을 관계의 행동적 구성요소로 본다.

\subsection{3. 협동적 규범}

협동적 규범(cooperative norms)은 변화하는 조건에 대한 반웅 유연성(Heide and John 1992)과 단결을 포합하고, Macneil(1980)이 제안한 많은 관계 규범들을 포함하며, 관계의 보전을 중요한 목표로 하고 있다(Kaufmann and Stern 1988). 그러한 규범의 개발은 신뢰를 반영하는 것이며 상업적 교환에 있어서 지배의 양식(mode)으로 작용하며(Bradach and Eccles 1989), 유통경로에 있어서 조화를 성취하는 데 중심적인 역할율 한다(Anderson and Narus 1990; Morgan and Hunt 1994). 협동 규범들은 두 거래 당사자들이 상호적 그리고 각자의 목표를 공동으로 성취하기 위하여 함께 일하는 것에 대하여 가지는 기대률 반영한다. 두 회사가 변화하는 조건에 대하여 유연하게 반옹할 수 있으며, 공동의 책임으로 문제를 처리하는 협동적 규범은 두 회사가 개별적 목표를 달성하기 위한 독립적 노력에 초점을 두는 낮은 협동과 구별된다. 높은 정도의 협동은 Bonoma(1976)가 기술한 양방향 권력시스템과 일치되는 행동들을 제시하며, 이 경우 거래 당사자들온 개별적 퐤락적 계획을 이루기 위한 행동뿐만 아니라 연합체(union)를 유지하기 위한 행동올 한다. 협동규범들은 당사자들이 성공하기 위하여 함께 일하여야 한다는 것올 이해하는 방식으로 양 당사자가 행동한다는 것을 의미하며, 상대방의 필요에 대한 다른 상대방의 복종을 의미하지 않는다(Anderson and Narus 1990). 따라서 이러한 협동규범의 수용이 행동요인은 아니지만 함께 일하려는 의도률 반영하는 의미에서 관계지향성의 구성요소가 된다.

\subsection{4. 업무(운영)결속}

자원의존이론은 기업의 중요한 자원의 불충분성에서 기업간 의존성을 다루고, 자원의 흐름을 통제하고 정확하게 예측할 수 있도록 기업간의 공식적 또는 준공식적 연결관계룔 구축하고 교환관계률 구조화하려 한다고 본다. 또한 거래비용이론은 거래비용의 효율성을 위하여 체계적 구조화를 강조한다. 따라서 관계를 맺고있는 당사자 기업간의 상호연졀된(intercoupled) 시스템이 양 당사자들의 역할을 명시적 또는 암시적으로 규정하는 경향이 있다(Heide 1994). 기업간의 업무적 결속(operational linkages)은 구매자와 판매자간의 시스템, 절차, 그리고 일상적인 것들(routines)이 업무가 용이하게 실행되도록 연결되어있는 정도롤 나타낸다(Cannon and Perreualt 1999). 이러한 업무적 연결이 기업간의 재화, 서비스 또는 정보의 흐름을 용이하게 한다.

최근의 협동적 마케팅 프로그램뿐만 아니라 컴퓨터화된 재고관리와 주문 및 배달 시스템, JT(just-in-time) 수송 등이 여기에 포함된다(Frazier, Spekman, and O'neal 1988), 비숫한 맥락에서 IMP그룹(예를 들어, Johanson \& Mattson 1987)은 톡히 상호연결된 기술적 과정 또는 생산과정에 기초한 기술적 결속(technical bonds)를 고려한다. 
Robicheaux와 Coleman(1994)는 유통관계구조의 한차원을 반영하는 업무적 퉁합(operational integration) 개념을 업무적 결속과 유사하게 사용하였다. 따라서 업무졀속정도를 관계지향성의 행동적 구성요소로 간주한다.

이상예서 식별된 관계지향성 구성요소들의 수준에 의하여 관계지향성을 정의하고, 관계지향집단과 비관계지향집단을 구분하여 요약하면, 다음 <표 1 과 같울 것으로 기대 된다.

<표 1> 관계지향성집단별 관계지향성 구성요소들의 수준

\begin{tabular}{|c|c|c|}
\hline & 관계지향집단 & 비관계지향집단 \\
\hline 정보교환 & 높음 & 낮음 \\
조화노력 & 높음 & 낮음 \\
협동적 규범 & 높음 & 낮음 \\
업무결속 & 높음 & 낮음 \\
\hline
\end{tabular}

\section{2. 관계지향성 실중분석}

\subsection{1. 연구의 표본}

본 연구의 분석 단위는 톡정한 구매자-판매자 관계이다. 다차원적인 것으로서의 관계룔 촉진요소에 의하여 유형화하기 위해 업종을 건설업으로 국한시키고 실중분석을 하였다.

개념적으로 연구자는 공급자의 관점, 구매자의 관점 또는 둘 다의 관점에서 구매자-판매자 관계에 대한 자료를 수집해야겠지만, 본 연구는 $\mathrm{C}$ 지역의 전문건설업체를 대상으로 공급자의 입장에서 자료를 구하였다. 종합건설업체는 전문건설업체들 중에서 협력업체를 선정하고 그들과 지속적인 접촉을 한다. 공급자는 구매자의 제품창조를 위한 시스템자원요소이다.

설문지는 총 500 부가 우편으로 배포되어 185 부가 회수되었으며(회수율 $37 \%$ ), 이 중에서 분석에 부적합한 45 부를 제외한 140 부가 분석에 사용되었다.

\subsection{2. 변수의 측정}

\section{정보교환/조화노력/협동규범수용/업무(운영)결속}

가설을 검중하기 위해 사용된 모든 항목들은 웅답자들이 주어진 문장에 대하여 동의하는 정도(전혀 그렇지 않다/매우 그렇다)를 7점 척도를 이용하여 측정하였다.

정보교환은 Cannon과 Perreault(1999)의 정보교환 측정변수룰 사용하여 3개의 변수로 측정하였다.

조화노력은 $\mathrm{Jap}(1999)$ 의 조하노력 변수롤 사융하여 3 개의 변수로 측정하였다.

협동규범수용은 Cannon과 Perreault(1999)의 협동규범수용 측정변수를 사용하여 4개의 변수로 측정하였다.

업무결속은 $\mathrm{Jap}(1999)$ 의 업무결속 변수를 사용하여 3개의 변수로 측정하였다.

각 구성 개념의 측정문항은 <표 $2>$ 에 요약되어 있다. 


\subsection{3. 변수의 신뢰성 및 타당성}

각 구성개념의 다항목척도에 의한 신뢰성은 Cronbach's alpha를 통하여 측정하였다.

관계지향성집단분석에 앞서서 각 개넘에 대한 수렵타당성과 판별타당성울 검토하기 위해 확인적 요인분석을 실시하였다. 변수의 측정개념 및 신뢰성 평가와 타당성 평가 결과는 <표 $2>$ 와 같다. 각 측정 문항들이 해당요인에 유의미하게 적재되었고, 비관련 요인에 대한 요인 적재치는 의미가 없었다. 또한 각 구성개념에 대한 측정문항들의 요인적재량은 0.71 이상을 학보합으로서 측정 항목들간의 판별타당성과 수렴적 타당성을 입증하였다(Singh \& Rhoads 1991). 본 연구에서 구성개넘 측정치는 각 구성개념별로 측정문항을 합산하고 평균을 구하여 만들어졌으며, 군집분석에 이용되었다.

<표 2> 관계지향성 요인분석

\begin{tabular}{|c|c|c|c|c|c|c|c|}
\hline \multirow{2}{*}{\multicolumn{3}{|c|}{ 구성 개넘 }} & \multicolumn{4}{|c|}{8 인 } & \multirow{2}{*}{$\begin{array}{l}\text { 신뢰 } \\
\text { 계수 }\end{array}$} \\
\hline & & & 1 & 2 & 3 & 4 & \\
\hline 정보교환 & & $\begin{array}{l}\text { 비용정보공유 } \\
\text { 제품개발 미텅에 동참 } \\
\text { 수요공급에측을 함께 }\end{array}$ & $\begin{array}{l}0.858 \\
0.825 \\
0.806\end{array}$ & & & & 0.84 \\
\hline 조화노력 & & $\begin{array}{l}\text { 공동프로잭트 수행 } \\
\text { 사업기화개발 공동참여 } \\
\text { 상숭작용 방법 추구 }\end{array}$ & & $\begin{array}{l}0.897 \\
0.761 \\
0.638\end{array}$ & & & 0.82 \\
\hline $\begin{array}{c}\text { 협동규범 } \\
\text { 수용 }\end{array}$ & & $\begin{array}{l}\text { 문제해견에 공동 노력 } \\
\text { 상대방의 이익배려 } \\
\text { 상호간에 협력 } \\
\text { 협력위한 변화수용 }\end{array}$ & & & $\begin{array}{l}0.837 \\
0.665 \\
0.629 \\
0.624\end{array}$ & & 0.82 \\
\hline 업무결속 & & $\begin{array}{l}\text { 자사기업활동과 고객기업과의 돤련성 } \\
\text { 고객기업이 자사기업운영에 미치는 영향 } \\
\text { 자사기업운영과 고객기업운영과의 관련도 }\end{array}$ & & & & $\begin{array}{l}0.838 \\
0.701 \\
0.664\end{array}$ & 0.71 \\
\hline
\end{tabular}

2.2.4. 군집분석

<표 3> 각 군집의 관계촉진 요인에 대한 반웅

\begin{tabular}{|c|c|c|c|c|}
\hline 관계지향성 & $\begin{array}{c}\text { 관계지향집단 } \\
(\mathrm{n}=41)\end{array}$ & $\begin{array}{c}\text { 비관계지향집단 } \\
(\mathrm{n}=99)\end{array}$ & F값 & Sig \\
\hline 정보 교환 & 5.33 & 3.35 & 122.048 & .000 \\
\hline 조화 노력 & 5.17 & 3.95 & 89.457 & .000 \\
\hline 협동규범수용 & 5.27 & 3.92 & 64.786 & .000 \\
\hline 업무(운영)결속 & 5.66 & 4.04 & 237.433 & .000 \\
\hline
\end{tabular}

4개의 관계지향성구성요인들에 대하여 이론적으로 탐색하였는데, 밀접한 관계 또는 관계지향적인 기업간의 관계는 4 개의 구성요인 모두에서 높은 점수를 얻을 것으로 기대된다. 따라서, 본 연구에서는 K-mean 방법으로 군집을 2개로 나누어 관계지향성이 높은 관계지향집단과 관계지향성이 낮은 비관계지향집단으로 구분하고자 한다. 
군집분석결과 <표 3>에서 보는 바와 같이 관계촉진요인들의 점수가 높은 집단과 낮온 집단으로 구분되었다. 따라서 공급자시장에는 관계지향집단과 비관계지향집단이 있음을 알 수 있다.

\section{3. 관계의 지향성의 원인요인과 성과}

\section{1. 관계지향성의 원인요인}

군집분석에 의하여 관계지향정도에 따라 두 개의 집단(관계지향집단, 비관계지향집단)을 구분하였다. 다음에서는 관계지향성 영향요인을 탐색하고자 한다.

\subsection{1. 환경적 요인}

1) 환경의 역동성

조직은 외부의 힙으로부터 자신들을 보호하고 환경적 요구들과 협력하려는 노력의 일환으로 환경적 요소에 반웅한다(Thompson 1967; Zajac and Shortell 1989). Stern, El Ansary 과 Coughlan(1996)은 연결 구성원들이 다른 사람의 환경의 특징울 인식하지 못하더라도, 다른 희사의 행위와 전략에서 드러나는 이러한 환경의 간접적 효과들을 깨단는다고 주장하였다.

환경적 조건들올 찾는 것은 분류체계의 타당성, 이론적 적절성, 그리고 관리적 유용성을 높인다(Hunt 1991; Punj and Stewart 1983). 이들 조건을 확인하는 목적은 관계지향성에서의 분산을 더 많이 설명하는 철저한 예측변수들을 제공하려는 것이 아니라, 중요한 이론적 척도와 실제적 척도에 따라 관계지향성들이 어떻게 차이가 나는지를 조사함으로써 분류의 본질에 대한 추가적인 통찰력을 생성하기 위한 것이다. 환경적 요구는 가능한 기회가 얼마나 많은가를 나타내며, 양자의 행위들을 유지하기 위해 필요한 자원들을 확보하기 위한 양자의 능력에 영향을 미친다. 양자에 대한 환경의 요구가 높으면, 밀접하게 함께 일하도록 하고 가능한 자원과 기회들을 효과적으로 사용하기 위해 전략적 결과물을 생성하는데 필요한 투자들을 만들도록 하는 촉진제가 된다.

구매회사가 공급자들과 밀접한 관계를 이루게 되는 두 가지 동기(motivators)는 불확실성과 의존성을 관리하고자하는 욕구라는 것을 제안한다(Oliver 1990; Pfeffer and Salancik 1978). 구매조직의 경우, 불확실성이나 의존성은 공급시장의 외재적 특성들 또는 내재적, 상항적 요인들에 근거할 수 있다.

공급시장은 구매조직에게 운영에 펄요한 투입물(input)을 제공한다. 비록 다양한 공급시장요인들이 관계 형성에 영향을 미치지만, 두 가지 조건들-공급시장 역동성과 대안의 이용가능성-이 여러 문헌에서 폭넓게 인용되며 또한 본 연구의 구매회사와의 인터뷰에서도 나타났다. 공급시장 역동성은 한 회사의 공급시장에서 변화의 변동정도로 특징 지을 수 있다(Achrol and Stern 1988; Aldrich 1979). 그러한 변화는 단기 변동 또는 장기 변화일 수 있으며, 빠르게 변화하는 기술, 빈번한 가격변화, 또는 제품 이용가능성의 변동과 같은 요인들에 기인할 수 있다. 의미있는 공급시장 역동성은 구매조직에 불확실성과 위헙을 일으킬 수 있다. Dwyer와 Welsh(1985)는 연결 구성원들이 상이한, 조화롭지 못한 환경적 존재와 직면하면, 덜 공식화된 과정, 분산된 결정구조, 참여적 의사결정 둥에 -필수적으로, 
협력적 관계 구조에서- 의존하는 경향을 보인다는 것을 발견하였다. 이것은 희사가 변화 하는 시장에 적웅하고 새로운 제품을 생산하도록 하며(Lawrence and Lorsch 1967; Thompson 1967), 양자가 시장의 변화와 도전에 신속히 대응할 수 있도록 하는 유연성을 만들도록 한다(Mahoney and Pandian 1992; Wernerfelt and Aneel 1987). 그러한 환경에서 특정한 공급업자와의 더 긴밀한 상호작용은 미래의 전개에 대하여 배울 수 있고 또한 관리할 수 있는 기회를 창출할 수 있다.

따라서, 우리는 시장 역동성의 잠재적인 위헙과 보상이 고객과 공급자간의 관계 지향성에 영향을 미칠 것으로 가정한다.

가설 1: 환경의 역동성 지각수준은 관계지항성에 긍정적 영향을 미칠 것이다.

\section{2) 대안의 이용가능성}

대안의 이용가능성은 단순히 구매희사가 욕구를 만족시키기 위하여 대안적인 공급원천올 가지는 정도이다. 시장에서 공급자가 서로 경쟁할 때 시장은 준비된 공급원이 된다. 그러나 경쟁이 제약되거나 공급재화가 결핍되어 이용가능한 대안적 공급 원천이 없다는 것은 불확실성의 원천이 될 수 있으며(Achrol and Stern 1988), 구매회사는 의존적이 될 것이다 (Pfeffer and Salancik 1978). 결과적으로, 우리는 대안의 이용가능성이 구매자-판매자 관계의 본질에 영향을 미칠 것으로 기대한다.

한편 보완 능력은 상대 회사가 없었다면 얻을 수 없었을 만큼의 결과물을 양측이 함께 만들어 낼 수 있는 것처럼, 결정적인 능력올 제공하기 때문에 성공적인 협력에는 필수적인 것이다. 따라서, 보완적 능력의 조합은 양측이 불편하거나 친숙하지 못한 감정들은 제거 시키면서 잠재적인 전략적 결과물들에 집중하도록 한다.

가설 2: 대안의 이용가능성 수준은 관계지향성에 긍정적 영향올 미칠 것이다.

3) 공급의 중요성

공급의 중요성은 특정한 공급의 재무적, 전략적 의미에 대한 구매회사의 지각이다. 여기에, 우리는 구매회사의 목표에 대하여 구매가 미치는 영향에 초점을 둔다. 예를 들어, 제조운영 에서, 원자재나 부품들은 일상적인 유지(routine maintenance)와 수선품목(repair items)보다 구매회사의 제품(buying firm's own offering)의 성공에 중요할 것이다.

가설 3: 공급의 중요성 지각은 관계지향성에 긍정적 영향을 미칠 것이다.

\subsection{2. 상호호혜적 전략}

상호호혜적 전략은 전략적 제휴로 맺어진 기업듈이 상호협력올 전제로 하여 자신의 이익올 중시합과 동시에 파트너의 이익을 배려하고 상호결합에 따른 시너지 효과를 공유 하려는 전략을 의미한다(노형봉, 서윤주, 정주훈 2001). 누구와 어떤 자원율 거래할 것인가도 중요하지만 지속적 거래를 위한 전략도 중요하다. 즉 기업간의 제휴운영문제도 중요하다.

거래 비용 분석 문헌에서의 기희주의적 행위의 개념은 교활하게 자신의 이익을 추구하는 것이라 정의하고 있다(Williamson 1985). 그러므로 기회주의적 행위의 본질은 사람의 적절한 또는 요구되는 역할 행위에 대한 함축적이거나 명백한 약속의 기만적인 침해이다(John 1984). 기회주의적 행위는 상황적으로 취급되지 않고 명백한 약속의 
기만적인 침해로 간주되면 범죄이다. 졀과적으로 한 당사자가 자신의 파트너가 기회 주의적인 행위를 한다고 믿게 되면 그러한 지각온 신뢰의 감소를 유발하게 된다고 가정할 수 있다.

Heide(1994)는 기업간 지배의 유형을 3가지로 구분하고, 쌍방적 비시장지배관계의 형성은 지배구조에 대한 진입의 선택성과 공유가치의 수용에서 출발하고, 관계의 유지에서 사전의 쌍방적 적옹을 통한 적옹적 변화와 장기지향적이며 상호결합을 통한 시스템 관련적 이익분배태도표출 둥의 특징이 있다고 하였다. 비록 기만적이고 자기이익의 극대화가 거래비용 분석에 있어 자명한 이치이지만, 실중 연구들은 인간의 행위가 그렇게 이기주의적인 것만은 아니고 톡히 장기적인 관계에 있어서는 그렇지 않다는 점을 지적하고 있다(Bonoma 1976; John 1984), 따라서 관계의 유지에는 기희주의적 행동에서 탈피하여 상호호혜적 전략의 수행이 필요하다.

가설 4: 상호호혜성 수준은 관계지향성에 긍정적 영향을 미칠 것이다.

\subsection{3. 신뢰성}

Morgan과 Hunt(1994)는 관계성에 관한 폭넓은 마케팅 문헌고찰을 퉁하여, 신뢰와 물입이 성공적인 관계적 교환에 주요 매개변수라는 것율 이론화하였다. 파트너와의 관계효익과 비용, 공유된 가치, 기희주의적 행동과 커뮤니케이션 방법 둥이 신뢰와 믈입을 매개로 고객행동에 영향을 미침을 가악하였다. 신뢰는 관계에 있어서 다른 쪽의 행위를 믿을 수 있을 만큼 예측할 수 있는 능력이며 다른 쪽이 기희가 주어지더라도 기희주의적으로 행동하지 않을 것에 대한 밀음이다(Andaleeb 1992; Anderson and Narus 1990; Deutsch 1969). Dwyer, Schurr와 Oh(1987)의 관계의 5 단계(인지, 탐색, 확장, 몰입, 해체) 모형에서, 단계의 이동은 당사자들이 서로를 보는 방법에서 중요한 전환을 요구하고 있다. 신뢰의 정직요소는 탐색단계에서 형성되고 자비성(benevolence) 요소는 확장단계 즉, 당사자들이 미래의 상호 작용을 약속하기 위한 기대들을 형성하는 단계에 진입되어야 형성된다. 믈입단계는 구매자 와 판매자간의 관계에서 성숙정도가 가장 높은 단계로 당사자들이 관계를 유지하기 위하여 의도적으로 자원을 개입시키는 특징이 있는 단계인데, 당사자들간의 몰입은 이러한 몰입단계에 진입되면서 나타나게 된다. 신뢰를 위한 정직성이 구체적이고 가시적인 관계의 측면과 주로 관련되고, 따라서 물입보다 좀 더 빨리 형성된다.

따라서 Williamson(1993)이 거래 관계는 계산적이라고 주장하였고 신뢰률 효율성과 신빙성 이라는 말로 설명하고, 신뢰는 일시적인 것이며 경제적 거래에 거의 영향을 미치지 않는다고 지적하였지만, 신뢰는 상호 조직간 거래률 관리하고 조화시키는 사희적 규범 중 하나로서(Morgan and Hunt 1994), 교환에 있어서 영역의 확장을 담당하는 구성원들 사이의 관계를 분명하게 만들고 톡별한 투자률 하도록 촉진하는 양자의 졀정에 영향을 미칠 수 있는 미시적 요소이며, 상호 조직관계의 변화하는 구조를 구성하고 수정하는데 대단히 중요한 측면이며 시장 거래에 대한 필수 선행 요건이다(Ring and Van de Ven 1992, 1994).

이러한 상호 인간적인 신뢰에 대한 믿음은 양자적 조화 노력과 톡이 투자에 대한 중요한 촉진제가 될 것으로 기대되며, 적절한 생각과 의미 있는 정보를 공유하도록 정보교환을 촉진시키고, 목표와 문제률 분명히 하고 문제-해결 지향적인 태도로 관계에 접근하도록 하는 협동적 규범올 수용하게 할 것이다. 
가설 5: 신뢰성수준은 관계지향성에 긍정적 영향을 미칠 것이다.

\section{2 관계지향성의 성과}

구매자와 공급자가 전략적 결과물의 성취에 자극을 받는다면 조화 노력과 거래특유투자에 관련한 위험을 기꺼이 감수하려 한다. 협력예 관한 많은 연구들이 성과 변수와 개인적 만족에 중점을 두어 왔다(Smith, Carroll, and Ashford 1995). 그러나, 밀접한 관계의 이익의 많은 부분은 경제적 용어로 쉽게 표현되지 않는다(예를 들어, 시장에 대한 제품의 빠른 수명주기, 높은 수준의 의사 결정, 향상된 경쟁력). 따라서 관계의 이익은 훨씬 광범위하고 포괄적으로 연구될 필요가 있다. $\mathrm{Jap}(1999)$ 은 기업간의 밀접한 상호관계로부터 나오는 전략적 보상의 특징에 대한 연구가 거의 없었다고 지적하고, 양자적 이익성과와 실현된 경쟁우위를 검토하였다.

\subsection{1. 실현 경쟁우위}

협력적 행위에 관여하게 하는 기초적인 동기 중 하나는 경쟁적 우워의 성취이다(예를 들면, 자원에 대한 보다 높은 차원의 접근, 공급과 개발비용의 감소, 독특한 과정 기술의 개발). Poter(1991)는 “자원은 경쟁적 우위을 얼으려는 어떤 행위를 수행하는 상황에서만 그 의미를 가진다”라고 주장하였다. 실현 경쟁우위 (realized competitive advantages)는 시장에서 양자가 보다 효과적으로 경쟁할 수 있도록 하는 경쟁 양자로부터 얻어지는 전략적 이익이다. 경쟁자가 양자의 협력 과정올 복제하려 하지만, 궙게 관찰되지 않으며, 경쟁자가 학습 곡선을 따라 움직이는 협력과정의 관리와 조화능력을 복제하기 위해서는 상당한 시간과 노력을 기울여야만 한다. 그런 결과로, 구매자와 공급자 사이에서 생겨나는 독특하고 깊은 관계는 양자가 다른 경쟁하는 양자들보다 효과적으로 경쟁할 수 있도록 하는 중요한 우위를 창출할 수 있다.

이러한 두 가지 결과물(양자적 이익 성과와 실현 경쟁우위)은 함께 얻어지며 일상적 이고 적당히 거리를 두는 거래 관계에서는 쉅게 발견되지 않는다. 관계지향성 (관계지향 집단과 비관계지향집단)에 따라 실현경쟁우위는 달라질 것이다.

가설 6: 관계지향성에 따라서 실현경쟁우위정도는 다를 것이다.

\subsection{2. 관계유지의도}

거래적 교환은 최소한의 개인적 관계에 의해서 또는 차후의 교환에 대한 예측이나 의무감이 없이 상품이나 성과를 대가로 받고 구매자와 판매자가 불연속적으로 교환하는 것이다. 반면, 관계마케팅은 기업 당사자간의 관계를 지속적으로 유지합으로서 상호간의 이익을 도모하는 교환인 것이다.

Jackson(1985)은 기업이 교환에서 거래적 개념을 적용할 것인가 아니면 관계적 개념을 적용할 것인가는 기업 스스로의 전략적 판단에 의해서 보다는 기업과의 관계에 대한 고객의 지향성에 따라서 달라져야함올 최초로 주장하였다. 이러한 Jackson(1985)의 아이디어를 바탕으로 하여 Anderson과 Narus(1990)는 거래적 교환에서 협동적 교환에 이르는 연속선상의 관점에서 고객을 분류해야 함을 주장하였다.

경쟁적 우위를 만들어 내기 위해서 희사는 그들의 자원올 전문화 시켜야 하며, 그들 
스스로를 차별화 시켜야 한다(Amit and Schoemaker 1993). 관계지향성은 이러한 시스템자원의 형성에 그 의미가 있다. 적당한 거리를 유지하는 교환은 모방할 수 없는 특이함이 결여되어 있으므로 적당한 거리두기 교환에서 벗어나서 특유의 투자, 지식 교환, 보완적 눙력, 그리고 보다 효과적인 관리 메커니즘을 통해 그들의 관계를 전문화시킴으로써 경쟁적 우위률 얻을 수 있는 기회를 만들어 낼 수 있다.

따라서, 관계지향적 기업은 비관계지향적 기업에 비해 지속적인 관계를 유지하고자 하는 의도를 갖게 될 것이다.

가설 7: 관계지향성에 따라서 관계유지의도는 다를 것이다.

\section{3. 연구모형}

이상에서 설명된 가설을 중심으로 연구모형을 설정하면 다음 <그림 $1>$ 과 같다.

<그림 1> 연구모형

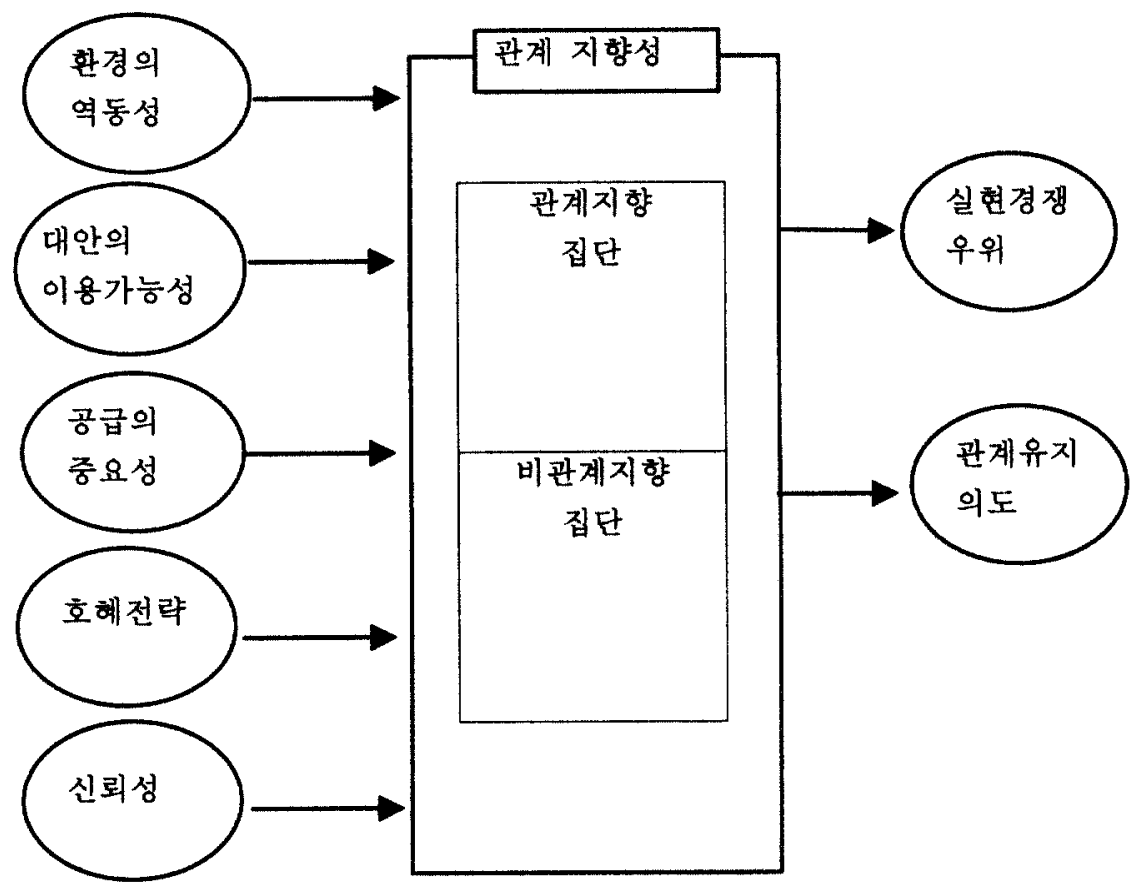




\section{4. 관계지향성의 원인과 성과에 대한 실중분석}

\section{1. 변수의 측정}

관계지향성의 원인과 성과에 대한 구성개념들의 측정문항은 <표 $4>$ 에 요약되어 있다.

4.1.1 시장환경의 역동성/기업의 대안 이용가능성/공급의 중요성/호혜전략/신뢰성 시장환경의 역동성은 Jap(1999)의 시장환경 역동성측정변수롤 사용하여 2 개의 변수로 측정하였다.

기업의 대안이용가능성은 Cannon과 Perreault(1999)의 기업의 대체가능성의 측정변수를 사용하여 2 개의 변수로 측정하였다.

공급의 중요성은 Cannon과 Perreault(1999)의 공급의 중요성 측정변수를 사용하여 3 개의 변수로 측정하였다.

호혜전략은 노형봉, 서윤주, 정주훈(2001)의 연구에서 변수를 추출하였다. 노형봉, 서윤주, 정주훈(2001)은 다음과 같은 세 가지 상호호혜적 전략을 제안하고 있다. 첫째, 가치-공유적 조정노력(value-shared coordination effort)으로써 기업이 파트너 기업과의 상호결합에서 창출되는 경쟁우위 및 가치에 대하여 커뮤니케이션하고 공유하려는 것을 의미한다. 둘째, 일치성-중심 조정노력(congruity-focused coordination effort)으로써 전략적 제휴의 운영과정에서 발생하는 의사졀정 상황에서 한 쪽 기업의 이익보다는 공동목표에 부합하는 것인지의 여부률 통하여 의사결정하려고 하는 것을 의미한다. 셋째, 친교적 조정노력(friendship coordination effort)으로써 상호 공식적 및 비공식적 채널을 통하여 친분을 유지하며, 빈번한 커뮤니케이션을 통하여 파트너 기업의 특수성과 문화를 이해하고자 노력하는 것을 의미한다.

신뢰성은 $\mathrm{Jap}(1999)$ 의 신뢰성 변수률 사용하여 4 개의 변수로 측정하였다.

\subsection{2. 실현경쟁우위/관계유지의도}

실현경쟁우위는 Jap(1999)의 실현경쟁우위 변수를 사용하여 2 개의 변수로 측정하였다.

관계유지의도는 노형봉, 서윤주, 정주훈(2001)의 관계유지의도 측정변수를 사용하여 5 개의 변수로 측정하였다.

\section{2. 변수의 신뢰성 및 타당성}

변수의 측정개념 및 신뢰계수와 타당성 평가결과는 <표 4>와 같다.

관계지향성요인과 성과에 관한 가설검중에 앞서서 각 개념에 대한 수렴타당성과 판별타당성을 검토하기 위해 확인적 요인분석을 실시하였다. 각 측정 문항들이 해당요인에 유의미하게 적재되었고, 각 구성개념에 대한 측정문항둘의 요인적재량이 0.4 이상으로 나타나고, 또 $a$ 값이 0.7 이상으로 나타나 수렵타당성이 확보되었고, 비관련요인에 대한 측정 문항의 적재량이 0.3 이하로 나타나 판별타당성이 확보되었다. 
<표 4> 각 개념에 대한 요인분석

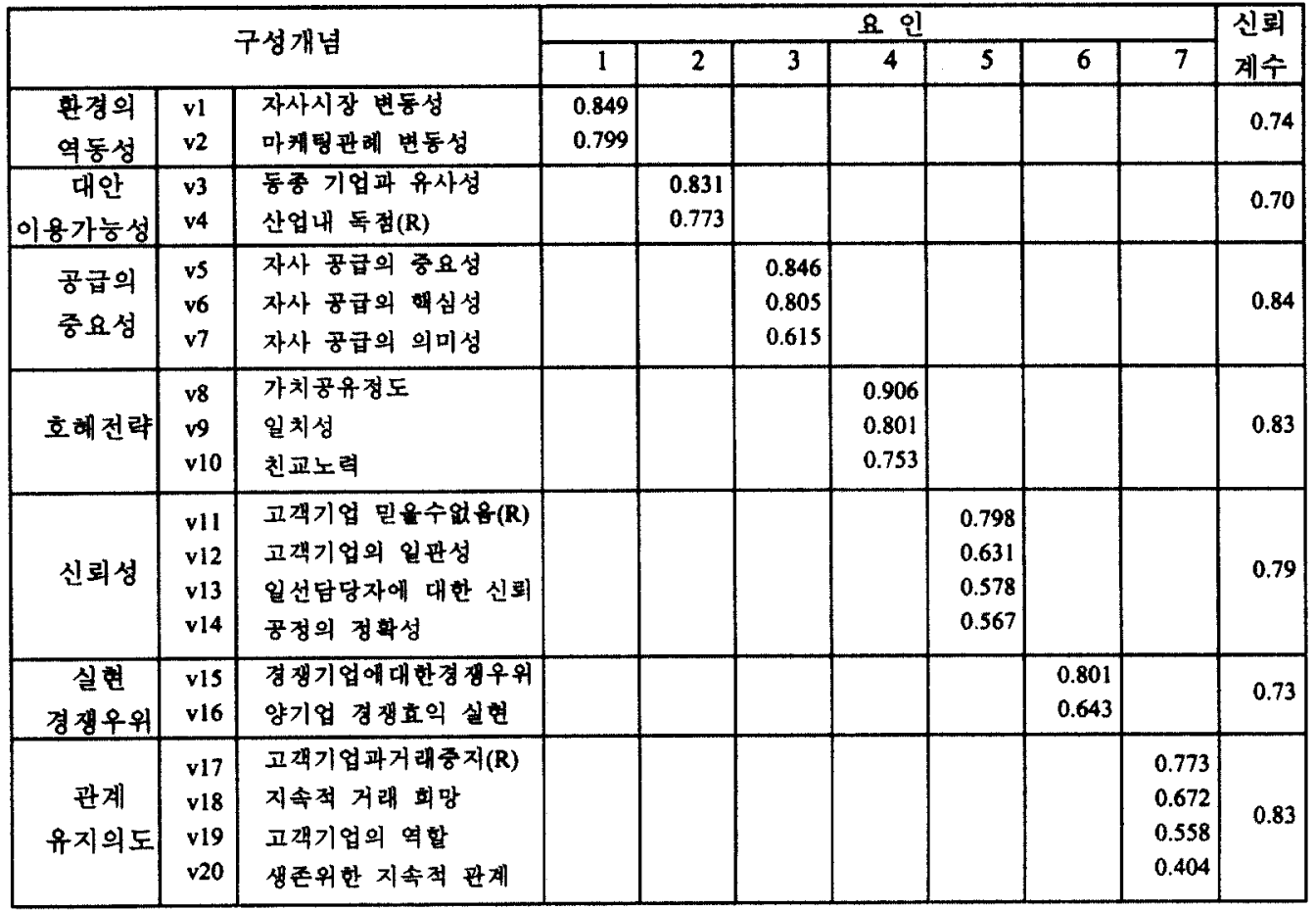

\section{3. 관계지향성의 원인변수 분석}

본 연구에서 선정한 관계지향성에 대한 영향요인들이 관계지향집 단과 비관계지향집단으로 분류하는데 얼마나 유용하게 이용될 수 있는가를 알아보기 위해 판별분석을 실시하였다. <표 5>는 집단 평균의 동절성에 대한 검정을 나타낸 표이다. 환경의 역동성, 대안의 이용가눙성, 공급의 중요성은 관계지향성정도에 따라 차이가 없는 것으로 나타났으며, 호혜전략, 신뢰성은 관계지향성정도에 따라 차이가 있는 것으로 나타났다.

<표 5> 집단 평균의 동질성에 대한 검정

\begin{tabular}{|c|c|c|c|c|c|}
\hline & Wilk's Lambda & F & 자유도 1 & 자유도 2 & 유의도 \\
\hline 환경의 역동성(H1) & 0.999 & 0.114 & 1 & 138 & 0.737 \\
대안의 이용가능성(H2) & 0.997 & 0.367 & 1 & 138 & 0.214 \\
공급의 중요성(H3) & 0.989 & 1.560 & 1 & 138 & 0.564 \\
호혜전략(H4) & 0.662 & 70.320 & 1 & 138 & 0.000 \\
신뢰성(H5) & 0.656 & 72.445 & 1 & 138 & 0.000 \\
\hline
\end{tabular}

분석 결과 가설 $1,2,3$ 은 기각되고, 가설 4,5 는 채택되었다.

Box' M 퉁계량을 퉁해 집단간에 공분산이 동일한가를 판단하게 되는데, 통계량이 14.788, F-값의 유의도가 0.522 로서 두 집단간에 공분산이 동일하다는 가정을 기각할 수 없으므로, 
판별분석에 적합한 자료임을 알 수 있다.

<표 6>온 정준판별함수로서 정준상관계수, 아이겐값, 윌크스 랍다(Wilk's lamda)를 제시 하여 판별함수 전체의 설명력을 나타내고 있다.

<표 6> 정준판별함수

\begin{tabular}{|c|c|c|c|c|c|c|}
\hline 합수 & 아이겐값 & $\begin{array}{c}\text { 정준상관 } \\
\text { 계수 }\end{array}$ & $\begin{array}{c}\text { 월크스 } \\
\text { 람다 }\end{array}$ & $\begin{array}{c}\text { 카이 } \\
\text { 스퀘어 }\end{array}$ & 자유도 & 유의도 \\
\hline 1 & 0.770 & 0.660 & 0.565 & 77.355 & 5 & 0.000 \\
\hline
\end{tabular}

정준상관계수(canonical correlation coefficient)는 판별식에 의해 설명되는 판별점수의 분산을 총분산으로 나누고 이률 제곱근 한 것으로 판별점수와 집단간의 상관관계를 나타내는데, <표 6>에 나타난 바와 같이, 정준상관계수가 0.660 으로서 판별력이 비교적 높다고 할 수 있으며, $5 \%$ 유의수준에서 판별식이 두 집단간에 차이가 없다는 귀무가설올 기각하게 되어 집단간에 차이가 있음을 보여주고 있다.

<표 7>는 판별분석에서 도출된 표준화된 판별함수의 계수를 보여주고 있으며, 판별 분석에서 도출된 판별함수를 가지고 관계지향성집단을 분류할 수가 있음을 보여주고 있다. 관계지향성집단을 분류하는데 가장 설명력이 큰 변수는 신뢰성임을 알 수 있다. 또한, <표 $8>$ 에서 보듯이 정확하게 분류된 기업의 비율이 $85 \%$ 이므로, 본 연구에서 사용된 관계지향성집단 구분에 영향을 미치는 요인들이 비교적 타당성 있게 선별되었음을 나타내주고 있다.

<표 7>판별분석에서 사용된 변수들의 판별계수

\begin{tabular}{|c|c|}
\hline 판별변수 & 표준화된 판별함수의 \\
\hline 환경의 역동성 & -0.210 \\
대안 이용가눙성 & 0.155 \\
공급의 중요성 & 0.115 \\
호혜전략 & 0.528 \\
신뢰성 & 0.655 \\
\hline
\end{tabular}

<표 8> 판별합수를 이용한 분석표본의 분류결과

\begin{tabular}{|c|c|c|c|c|}
\hline & & \multirow{2}{*}{ 표본 수 } & \multicolumn{2}{|c|}{ 예측 그룹 } \\
\hline & & & 관계지향집 & 비관계지향집 \\
\hline \multirow{2}{*}{ 원 래그릅 } & 관계지 향집단 & 41 & $29(70.7 \%)$ & $12(29.3 \%)$ \\
\hline & 비관계지향집 & 99 & $9(9.1 \%)$ & $90(90.9 \%)$ \\
\hline
\end{tabular}

4.4. 관계지향집단과 비관계지향집단간의 성과변수 분석

관계지향성이 성과에 어떠한 영향을 미치는가를 검중하기 위해 MANOVA(multivariate 
analysis of variance)분석을 실시하였다. <표 9>는 관계지향집단과 비관계지향집단간의 성과차이에 대한 기술적 통계량을 나타내고 있다.

<표 9> 기술적 뽕계량

\begin{tabular}{|c|c|c|c|c|}
\hline \multicolumn{2}{|c|}{} & 평균 & 표준화된 편차 & N \\
\hline \multirow{2}{*}{ 실현경쟁이익 } & 관계지향집단 & 5.4390 & 0.8000 & 41 \\
& 비관계지향집 & 3.9545 & 0.8809 & 99 \\
\hline \multirow{2}{*}{ 관계유지의도 } & 관계지향집단 & 5.8829 & 1.0816 & 41 \\
& 비관계지향집 & 4.6747 & 0.9448 & 99 \\
\hline
\end{tabular}

<표 $10>$ 은 다변량 분산분석 검정결과이며, 유의도 $5 \%$ 에서 통계적으로 유의함을 보여주고 있다.

<표 10> 다변량 분산분석 검정결과

\begin{tabular}{|c|c|c|c|c|c|}
\hline 검정방법 & $\begin{array}{c}\text { 검정퉁계 } \\
\text { 량 }\end{array}$ & F-통계량 & $\begin{array}{c}\text { 분자의 } \\
\text { 자유도 }\end{array}$ & $\begin{array}{c}\text { 분모의 } \\
\text { 자유도 }\end{array}$ & 유의도 \\
\hline Pillai's & 0.973 & 2428.524 & 2 & 137 & 0.000 \\
Wilks' & 0.027 & 2428.524 & 2 & 137 & 0.000 \\
Hotelling's & 35.453 & 2428.524 & 2 & 137 & 0.000 \\
Roy's & 35.453 & 2428.524 & 2 & 137 & 0.000 \\
\hline
\end{tabular}

<표 11>은 분산분석결과이며, 유의도 $5 \%$ 에서 퉇계적으로 유의함을 보여주고 있다.

<표 11> 집단간 분산분석결과

\begin{tabular}{|c|c|c|c|c|c|}
\hline 종속변수 & 독립변수 & $\begin{array}{l}\text { Sum of } \\
\text { Squares }\end{array}$ & 자유도 & $\mathbf{F}$ & 유의도 \\
\hline $\begin{array}{c}\text { 실현경쟁이 } \\
\text { 익 }\end{array}$ & $\begin{array}{c}\text { 관계지향성 } \\
\text { error } \\
\text { Total }\end{array}$ & $\begin{array}{r}63.891^{\star} \\
101.643 \\
2862.750\end{array}$ & $\begin{array}{r}1 \\
138 \\
140\end{array}$ & 86.744 & 0.000 \\
\hline $\begin{array}{l}\text { 관계유지의 } \\
\quad \text { 도 }\end{array}$ & $\begin{array}{c}\text { 관계지향성 } \\
\text { error } \\
\text { total }\end{array}$ & $\begin{array}{r}42.321^{b} \\
134.285 \\
3716.720\end{array}$ & $\begin{array}{r}1 \\
138 \\
140\end{array}$ & 43.492 & 0.000 \\
\hline \multicolumn{6}{|c|}{$\begin{array}{l}\text { a. } R^{2}=0.386 \text { (Adjusted } R^{2}=0.382 \text { ) } \\
\text { b. } R^{2}=0.240 \text { (Adjusted } R^{2}=0.234 \text { ) }\end{array}$} \\
\hline
\end{tabular}

다변량 분산분석의 결과는 관계지향성, 즉 관계정도가 높은 관계지향집단과 관계정도가 낮은 비관계지향집단간에 성과, 즉 실현경쟁이익과 관계유지의도가 다른 것으로 검중되었다. 다시 말해, 관계 정도가 높은 집단이 관계 정도가 낮은 집단보다 실현 경쟁이익 수준을 높게 지각하고 관계를 유지하려는 의도가 높은 것으로 나타났다. 가설 6,7 은 채택되었다. 


\section{5. 결 론}

\section{1 연구의 요약}

기업들온 그들이 수행하는 분야의 기눙에 있어서는 서로 다를 수 있지만, 그들 관계의 기초가 되는 행위 구성에 대한 원인의 톡성과 패턴은 서로 비슷할 것으로 생각된다. 본 연구는 양자의 개별적인 인식에 대한 것이 아니라 협력적 과정을 추구하는 당사자들간의 상호관계에 중점을 두었으며, 재정적으로 독립적인 구매자와 공급자사이의 수직적 관계와 관련된다.

본 연구는 공급기업-구매기업간의 관계지향성이 어떻게 나타나는지를 분석하고, 관계지향 행동을 구성하는 요인에는 어떠한 요인들이 있으며, 이러한 관계지향구성행동에 따라 관계를 맺은 기업간의 관계성과에는 어떠한 차이가 있는지를 검중하고자 하였다.

관계구성요소로는 거래비용이론, 자원의존이론, 관계계약이론에 근거하여, 정보교환, 업무졀속, 조화노력, 협동규범 변수를 도출하였고, 기업데이터를 군집분석하여 정보교환, 업무결속, 조화노력, 협동규범수용이 높은 집단(관계지향집단)과 낮은 집단 (비관계 지향 집단)으로 구분하였다.

관계지향성의 영향요인으로는 공급시장환경의 역동성, 기업의 대안 이용가능성, 공급의 중요성, 호혜전략, 신뢰성을 들고 이러한 관계지향성의 영향요인이 관계지향성에 미치는 영향을 분석하기 위해서 판별분석을 사용하였다. 판별분석 결과 본 연구에서 사용된 관계지향성요인들 중에서 호혜전략과 신뢰성이 의미 있는 변수로 식별되었고, 환경의 역동성, 대안의 이용가능성, 공급의 중요성 변수는 관계지향성을 설명하지 못하는 것으로 나타넜다. 즉, 공급기업과 구매기업간의 관계지향성을 결정하는데 있어서, 기업의 환경 보다는 사희심리적 변수인 신뢰성과 전략변수인 호혜적 전략이 중요하게 나타났다. 이것은 건설업계에서는 신뢰를 기반으로한 다년간의 관계형성과 기업간의 가치공유, 일치성, 친교 노력을 퉁한 호혜적 전략이 중요함을 알 수 있게 한다. 환경의 역동성은 유의적이지는 못하였지만, 음의 계수로 나타났는데, 이는 환경이 역동적일수록 관계지향성을 따르지 않는 것을 의미한다. 이는 환경의 변화가 심한 경우 기업은 위헙에 노출되기 때문에 기존의 관계 고수 보다는 단속적으로 거래하는 경향이 있는 것으로 보인다. 특히, 본 연구의 설문 대상 기업들이 건설관련 기업으로서 IMF와 같은 환경변화 속에서 연쇄도산을 피하기 위해 기존 관계 기업간의 협력적 관계보다는 일시적인 관계를 통해 자구책을 모색하고자 했던 예 들에서 일시적으로 나타난 현상이 아닌가 생각된다.

한편 관계지향성의 성과변수분석에서 비관계지향집단보다 관계지향집단에서 실현경쟁 우위의 수준이나 관계유지의도가 높은 것으로 나타났다.

\section{2. 시사점 및 미래연구}

\subsection{1. 시사점}

본 연구는 관계결속에 필요한 관계지향행동요소를 이론적으로, 실중적으로 검토하여, 정보교환, 업무적 결속, 조화 노력, 협동규범의 수용 둥이 관계결속의 구성요소임을 식별하였다. 또한 관계지향적인 기업의 실현 경쟁우위와 관계지속의도가 높은 것올 
발견하였다.

특히, 관계지향집단의 경우에 관계지향적 행동구성요소들의 수준이 모두 높게 나타나고, 비관계지향집단의 경우에 관계지향적 행동구성요소둘의 수준이 모두 낮게 나타남을 이론적으로 또 실증젹으로 확인하였다. 따라서 본 연구는 관계지향성수준은 식별된 관계지향구성요소들을 동시에 고려하여 설명되어야 함을 확인시켜줌으로서 이론적 시사점올 제시한다. 또한 관계지향성수준에 신뢰성과 호혜성의 인식이 영향을 미침을 보여 기업간 관계의 지향정도와 유지에 심리변수와 호혜 전략이 중요함을 제시한다.

또한 실무적으로 기업의 실현경쟁우위를 높이고 관계지속의 의도를 갖도록 하기 위해서는 비시장적 지배의 관점에서 관계지향행동구성요소에 대한 관리적 검토가 필요하며, 구성요소별로 구체적인 지침을 마련하고 이에 따른 실행이 있어야 한다. 기업이 실현경쟁우위를 높임으로서 장기적인 관계를 형성해 온 기업 양자는 보다 효과적으로 경쟁할 수 있도록 하는 전략적 우위를 창출할 수 있으며, 관계유지의도를 형성하게 됨으로서, 단속적 거래에서 장기적 거래로 발전해감으로서 관계마케팅의 관점에서의 잇점을 얻을 수 있을 것이다.

한편, 대안의 이용가능성, 공급의 중요성 변수가 관계지향성을 설명하지 못하는 것으로 나타났는데, 이는 건설시장에서 공급자간의 과당경쟁과 차별화의 부재현상으로 추측된다. 하지만, 구매자의 신뢰와 호혜전략을 기반으로 형성된 관계지향적 기업에서는 경쟁우위가 실현되고 있으며, 관계를 계속적으로 유지하려는 것으로 나타나 건설시장의 불황에도 불구하고 살아남는 기업은 기업간의 비시장지배적인 수직적 관계를 유지하고 있음을 시사한다.

또한 본 연구졀과에 따르면, 구매기업은 공급기업에 대하여 무엇보다 신뢰성을 확보, 유지해야 하며, 일치성, 친교노력, 가치의 공유를 기반으로 하는 호혜전략을 수행하여 공급기업의 관계결속을 유도해야 한다. Dwyer와 Welsh(1985)는 조직 구성원들이 상이한 환경존재와 직면하면, 덜 공식화된 과정, 분산된 결정구조, 참여적 의사결정 둥에 의존하는 경향을 보인다고 하였는데, 본 연구과정에서의 관계지향성의 원인변수에서 나타나듯이 신뢰성과 전략적 측면이 더욱 중시됨을 알 수 있다.

\subsection{2. 한계점과 미래의 연구내용}

한편, 본 연구는 이러한 시사점에도 불구하고 다음과 같은 한계점과 미래 연구내용을 갖고 있다.

본 연구는 관계의 유형을 구분하기 위하여 자원의존이론, 거래비용이론, 관계계약 이론에서 관계촉진요소룔 탐색하였고, 군집분석에 의하여 두 개의 집단 즉 관계수준이 관계지향 집단과 비관계지향 집단으로 구분하였다. 그러나 관계특유투자와 같은 촉진요소는 본 연구에서 제외되었다. 물론 구조적으로 결속이 될 수 있는 거래톡유투자는 치열한 경쟁이 있는 건설시장에 의미가 없을 것으로 연구자가 판단하여 제외시켰지만, 차후의 반복연구에서는 고려해야 할 것으로 판단된다.

또한 본 연구에서 환경요인 즉 공급시장 환경의 역동성, 대안 이용가능성, 공급의 중요성, 등의 변수가 비유의적으로 나타넜다. 그러나 공급기업이 자사제품의 차별화룰 시도한다면 이러한 환경요인들의 의미는 더욱 중요할 것으로 여겨진다. 따라서 제품의 차별화 정도를 구매자의 관점에서 검토하고 환경요인을 분석해야 할 것이다.

그리고 본 연구는 시장지향성과 관계지향성간의 관계를 전혀 언급하지 못하고 있다. 
시장지향성(market orientation)은 시장 정보의 창출예 있어서 관련자들이 모두 참여하고, 그 정보를 전파하며, 반웅행동을 나타내고, 시장의 범위에 최종 고객들뿐만 아니라 유통업자 둥의 조직을 포함시킴으로서 보다 광범위한 시장관리를 반영하고 있다. 시장지향성은 고객지향성, 경쟁자 지향성, 부서간 조정 둥으로 구성된다고 보며, 현재 및 미래의 고객욕구를 반영하는 시장정보를 전사적 (organization-wide) 차원에서 창출하고, 창출된 정보를 조직 전체에 교류시키며, 그 시장정보에 대해 전사적으로 반웅하는 것이다. 정보 교류는 조직내 전부서의 실질적 참여를 통하여 시장욕구에 효과적으로 반웅하는 것을 의미 하며, 조직은 시장욕구에 부웅하기 위해 시장 정보를 조직내의 관련부서와 관련조직 및 개인들에게 전파하고 의사소통시켜야 한다는 것이다. 따라서 차후의 연구에서는 조화노력 업무결속 정보교환 등의 효율성을 높일 수 있는 시장지향성의 실현체제와 관계지향성간의 관계를 검토할 필요가 있다.

끝으로, 본 연구에 이용된 자료는 공급자 측면에서 이루어진 횡단면자료이기 때문에, 거래관계의 질적 특성이 거래 당사자간의 거래가 역사적으로 어떻게 발전되어왔는가를 파악하지 못하고 있다. 따라서 장기적인 자료를 분석하는 것이 보다 바람직하다고 판단된다. 


\section{<참고문헌>}

노형봉, 서윤주, 정주훈(2001), "국내기업간 전략적 제휴의 핵심성공요인에 간한 연구 : 상호 호혜적 조정전략을 중심으로,“ 경영학 연구, 30(1), 75-108.

Achrol, Ravi Singh. and Louis W. Stern (1988), "Environmental Determinants of Decision-Making Uncertainty in Marketing Channels, " Journal of Marketing Research, 25 (February), 36 - 50. Aldrich, Howard E. (1979), Organizations and Environments. Englewood Cliffs, NJ: Prentice Hall.

Amit, R. and P. Shoemaker (1993), "Strategic Assets and Organizational Rent," Strategic Management Journal, 14 (1), 33-46.

Andaleeb, Syed Saad (1992), "The Trust Concept : Research Issues for Channels of Distribution," Research in marketing, 11, 1-34.

Anderson, Erin M. and Barton A. Weitz (1992), "The Use of Pledges tp Build and Sustain Commitment in Distribution Channels," Journal of Marketing Research, 29 (February), 18-34. and Barton Weitz(1992), "The Use of Pledges to Build and Sustain Commitment in Distribution Channels," Journal of Marketing Research, 24 (February), 18-34

Anderson, James C. and James A. Narus (1990), "A Model of Distributor Firm and Manufacturer Firm Working Partnerships," Journal of Marketing, 54 (April), 42-58.

Anderson, James C.and James A. Narus (1984), "A Model of the Distributor's Perspective of Distributor Manufacturer Working Relationships." Journal of Marketing, 48 (Fall), 62 - 74. and (1990), "A Model of Distributor Firm and Manufacturer Firm Working Partnerships," Journal of Marketing, 54 (January), 42 - 58.

Becker, H. S. (1960), " Notes on the Concept of Commitment." American Journal of Sociology, 66 (3), 32 $-40$.

Bonoma, Thomas V (1976). "Conflict, Cooperation, and Trust in Three Power Systems." Behavioral Science, 21 (November), 499 - 514.

Bradach, Jeffrey L. and Robert G. Eccles (1989), "Price, Authority, and Trust." Annual Review of Sociology, 15, 97 - 118.

Burns, Tom and G. M. Stalker (1961), The Management of Innovation. London : Tavistock.

Cannon, Joseph P. and William D. Perreault Jr.(1999),"Buyer-seller Relationship in Business Market," Journal of Marketing Research, 36, 439-460.

Clopton, Stephen W. (1984). "Seller and Buying Firm Factors Affecting Industrial Buyers' Negotiation Behavior and Outcomes," Journal of Marketing Research, 21 (February), 39 - 53.

Das, T. K. and B. S Teng(1988), "Resource and Risk Management in the Startegic Alliance Making Process, " Journal of Management, 24(1), 1-15.

Deutsch, Morton (1969), "Conflicts; Productive and Destructive," Journal of Social Issues, 25(1), 7-41. Doney, Patricia M. and Joseph P. Cannon (1997), "An Examination of the Nature of Trust in Buyer Seller Relationships," Journal of Marketing, 61 (April), 35 - 51.

Dwyer, F. Robert, Paul Schurr, and Sejo Oh (1987), "Developing Buyer-Seller Relationships," Journal of marketing. 51 (April), 11-27. and Mary Ann Welsh(1985), "Environmental Relationships of the Internal Political Economy of Marketing Channels," Journal of Marketing Research, 22(November), 397-414.

Dyer, Jeffrey H. (1996), "Specialized Supplier Networks as a Source of Competitive Advantage : Evidence from the Auto Industry," Strategic Management Journal, 17 (4), 271-91. and Harbir Singh (1998), "The Relational View : Cooperative Strategy and Sources of Interorganizational Competitive Advantage," Academy of Management Review, 23 (4), 660-79. 
Eliashberg, Jehoshua and Donald A. Michie (1984), "Multiple Business Goal Sets as Determinants of Marketing Channel Conflict : An Empirical Study," Journal of Marketing Research, 21 (February), 75-88.

Emshwiller, John R. (1991), "Suppliers Struggle to Improve Quality as Big Firms Slash Their Vendor Rolls," The Wall Street Journal, (August 16), B1, B2

Frazier, Gary L. (1983), "Interorganizational Exchange Behavior in Marketing Channels: A Broadened Perspective," Journal of Marketing, 47 (Fall), 68 -78. Robert E. Spekman, and Charles R. O'Neal; (1988), "Just-in-Time Exchange Relationships in Industrial Markets," Journal of Marketing, 52 (October), 52 - 67.

Hallen, Laes, Jan Johanson, and Nazeem Seyed - Mohamed (1991), "Interfirm Adaptation in Business Relationships." Journal of Marketing, 55 (April), 29 - 37.

Heide, Jan B, (1994). "Interorganizational Govemance in Marketing Channels," Journal of Marketing, 58 (January), 71 - 85 .

and George John (1988). " The Role of Dependence Balancing in Safeguarding Transaction-Specific Assets in Conventional Channels," Journal of Marketing, 52 (January), 20 - 35. and _ (1990), "Alliances in Industrial Purchasing: The Determinants of Joint Action in Buyer - Supplier Relationships." Journal of Marketing Research, 27 (February), 24 - 36. and (1992). "Do Norms Matter in Marketing Relationships?" Journal of Marketing, 56 (April), 32 - 44.

Hennart, J. F.(1991), "The Transaction Cost Theory of Joint Venture : An Empirical Study of Japanese Subsidiaries in the United States," Management Science, 37(4), 483-497.

Hofstede, G.(1980), Culture's Consequences, Sage Publications, Beverly Hills, CA.

Hunt, Shelby D, (1991), Modern Marketing Theory, Cincinnati, OH: South - Western Publishing Co,Jackson, Barbara Bund (1985), Winning and Keeping Industrial Customers, Lexington, MA: Lexington Books.

Jap, Sandy D.(1999), "Pie-Expension Efforts: Collaboration Processes in Buyer-Supplier Relationships", Journal of Marketing Research, 461-475.

Jaworski, Bemard J, (1988), "Toward a Theory of Marketing Control: Environmental Context, Control Types, and Consequences," Journal of Marketing, 52 (July), 23-39.

Johanson, Jan and Lars-Gunnar Mattson (1987), "Interorganizational Relations in Industrial Systens: A Network Approach Compared with the Transaction-Cost Approach," International Studies of Management and Organization, 17 (Spring), 34-48.

John, George (1984). "An Empirical Investigation of Some Antecedents of Opportunism in a Marketing Channel," Journal of Marketing Research, 21 (August), 278 - 89.

John, George and Torger Reve (1982). "The Reliability and Validity of Key Informant Data from Dyadic Relationships in Marketing Channels,"Journal of Marketing Research, 19 (November), 517-24.

Kaufmann, Patrick J, and Louis W. Stern (1988), "Relational Exchange Norms, Perceptions of Unfairness, and Retained Hostility in Commercial Litigation," Journal of Conflict Resolution, 32 (September), 534-52.

Kelley, Harrold H. and John W. Thibaut (1978), Interpersonal Relations: A Theory of Interdependence. New York: John Wiley \& Sons

Kumar, Nirmalya, Lisa K, Scheer, and Jan-Benedict E. M. Steenkamp (1995), "The Effects of Perceived Interdependence on Dealer Attitudes, " Journal of Marketing Research, 32 (August), 348 - 56.

Lawrence, Paul R. and Jay W. Lorsch (1967), Organization and Environment. Boston, MA : Harvard University Press. 
Macaulay, Stewart (1963), " Non-Contractual Relations in Business: A Preliminary Study," American Sociological Review, 28 (February), 55-67.

Macneil, Ian (1980), The New Social Contract New Haven, CT: Yale University Press.

Magnet, Myron (1994), "The New Golden Rule of Business." Fortune, (February 21), 60-64.

Mahoney, J. T. and J. R. Pandian (1992), "The Resource-Based View Within The Conversation of Strategic Management,"Strategic Management Journal, 13 (5),363-80.

Mohr, Jakki, Robert J, Fisher, and John R. Nevin (1996). "Collaborative Communication in Integration and Control." Journal of Marketing, 60(July), 103-15.

Morgan, Robert M. and Shelby D, Hunt (1994), "The Commitment and Trust Theory in Relationship Maeketing." Journal of Marketing, 58 (July), 20-38.

Oliver, Christine (1990). "Determinants of Interorganizational Relationship: Integration and Future Directions." Academy of Management Review, 15(April). 241-65.

Pfeffer, Jeffrey and Gerald R. Salancik (1978). The External Control of Organizations" A Resource Dependence Approach. New York: Harper and Row Publishers.

Porter, Michael E. (1980), Competitive Strategy. New York : The Free Press.

(1985), Competitive Advantage. New York : The Free Press.

(1991), "Toward a Dynamic Theory of Strategy," Strategic Management Journal, 12 (Winter), 95-117.

Punj, Girish and David W. Stewart (1983). "Cluster Analysis in Marketing Research: Review and Suggestions for Application." Journal of Marketing Research, 20 (May), 134-48.

Reve, Torger (1986), "Organization for Distribution," in Research in Marketing, Vol. 8, L.P. Bucklin and James M. Carman, eds. Greenwich, CT: JAI Press, 1-26.

Rindfleisch, Aric and Jan B. Heide (1997), "Transaction Cost Analysis: Past, Present, and Future Applications," Journal of Marketing, 61 (October). 30-54.

Ring, Peter Smith and Andrew H. Van de Ven (1992), "Structuring Cooperative Relationships Between Organizations," Strategic Management Journal, 13 (7), 483-98.

and_(1994), "Developmental processes of Cooperative Interorganizational Relationships," Academy of Management Review, 19 (1), 90-118.

Robicheaux, Robert A, and James E, Coleman (1994), "The Structure of Marketing Channel Relationships," Marketing Science, 22 (Winter), 38-51.

Ruekert, Robert W., Orville C. Walker, Jr, and Kenneth J. Roering(1985), "The Organization of Marketing Activities: A Contingency Theory of Structure and 6Performance," Journal of Marketing, 49(winter), 13-25.

Rusbult, Caryl E, (1983), "A Longitudinal Test of the Investment Model: The Develipment (and Deterioration) of Satisfaction and Commitment in Heterosexual Involvements." Journal of Personality and Social Psychology, 45 (July), 101-17.

Schmidt, Stuart A. and Thomas A. Kochan (1977), "Interorganizational Relationships : Patterns and Motivators," Administrative Science Quarterly, 22 (June), 220-34.

Stern, Louis W., Adel El-Ansary, and Ann Coughlan (1996), Marketing Channels, 5th ed. Upper Saddle River, NJ : Prentice Hall.

Thompson, James (1967), Organizations in Action. New York : McGraw-Hill.

Weitz, Barton A. and Sandy D. Jap (1995), "Relationship Marketing and Distribution Channels," Journal of the Academy of Marketing Science, 23 (4), 305-20.

Williamson, O. E.(1985), The Economic Institutions of Capitalism, Free Press, New York. 
Wernerfelt, Birger (1984), "A Resource-Based View of The Firm," Strategic Management Journal, 5 (2), 171-80.

and Karnani Aneel (1987), "Competitive Strategy Under Uncertainty," Strategic Management Journal, 8(2), 187-94. 